\title{
Geomechanical effects of oilfield chemicals on sand failure in reservoir rocks
}

\author{
E.O. Wuyep ${ }^{1 *}$, G.F. Oluyemi ${ }^{1}$, K. Yates ${ }^{2}$, and A.R. Akisanya ${ }^{3}$ \\ ${ }^{1}$ School of Engineering, Robert Gordon University, Aberdeen, \\ AB10 7GJ, United Kingdom.

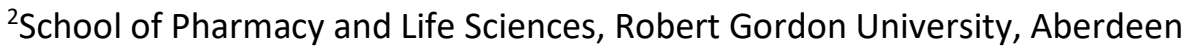 \\ AB10 7GJ, United Kingdom. \\ ${ }^{3}$ School of Engineering, University of Aberdeen, Aberdeen, \\ AB24 3UE, United Kingdom.
}

(Accepted for publication in Journal of Petroleum Science and Engineering, 16 Feb 2018)

\begin{abstract}
Sand failure may result in the production of formation sand at the same time the formation fluids are being produced. This work examines the effects of some commonly used oilfield chemicals, specifically, biocide, corrosion inhibitor and scale inhibitor, on the geomechanical strength of reservoir rocks such as limestone and sandstone. A combination of rock mechanical testing, grain size distribution analysis and analytical techniques are used to establish and define the effects of these chemicals on grain dissolution and unconstrained compressive strength. The results suggest that some interactions such as chemical reaction (dissolution/precipitation) between the oilfield chemicals and the two different types of reservoir formation rocks and transport of grains occurred following the exposure of the rocks to the oilfield chemicals leading to the weakening of the grain fabrics rocks and consequent reduction in unconfined compressive strength. The implications of the results for the strength reduction and sand production are discussed.
\end{abstract}

Keywords: Sand failure, oilfield chemicals, geomechanical strength, dissolution, mechanical testing, precipitation.

\section{INTRODUCTION}

Oilfield chemicals have a wide range of applications in oil and gas industry and have been used extensively as inhibitor, surfactant, biocide, stabilizer, depressant, retarder, scavenger, defoamer, demulsifier and stimulant. However, the potential deleterious geomechanical effects of these chemicals on the reservoir formation rock are often not considered by the current industry approach to geomechanical evaluation and prediction of sand failure of reservoir formations that have experienced substantial use of these chemicals. Geomechanical evaluation of the effects of these oilfield chemicals on the properties of the reservoir rock is required in the development of effective sand failure models (Oluyemi et al., 2010). The prediction and prevention of sand production in reservoir rocks has constantly given the oil and gas production engineers concern for decades. This phenomenon occurs when the formation stress exceeds the strength of the formation that is derived majorly from the natural materials that cement the sand grains and bonding by cohesive forces (Oyeneyin et al., 2005). A number of factors, including oilfield chemicals-formation interaction contribute to this phenomenon.

\footnotetext{
${ }^{*}$ Corresponding Author. Email: e.o.wuyep@rgu.ac.uk
} 
Previous works (Wilson, 2016; Oluyemi, 2014; Mohamed and Nasr-El-Din, 2013; Denney, 2013; Bybee, 2010; Egermann et al., 2010; Tomson et al., 2008; Metcalf and Devine, 2004) studied the effects of interaction between chemicals like hydrochloric acid $(\mathrm{HCl})$, carbon dioxide $\left(\mathrm{CO}_{2}\right)$, brine and water $\left(\mathrm{H}_{2} \mathrm{O}\right)$, diethylenetriamine penta (methylene phosphonic acid) (DETPMP), 2,2 bis(4-hydroxyphenyl)-4-methylpentane (BHPMP) and the formation rock on the strength and petrophysical properties of sandstone and carbonate rocks. These studies were carried out to: (i) determine the mechanisms involved in the chemistry of water flow back in the water/shale interaction (Wilson, 2016); (ii) establish a fundamental knowledge on the behaviour of carbonate and clastic rocks in the presence of scale inhibitor (Oluyemi, 2014; Tomson et al., 2008); (iii) investigate the effect of $\mathrm{CO}_{2}$-carbonate rock interaction on the strength and petrophysical properties of the rock (Mohamed and Nasr-El-Din, 2013; Denney, 2013; Egermann et al., 2010); (iv) investigate wellbore integrity as it relates to $\mathrm{CO}_{2}$ migration during $\mathrm{CO}_{2}$ /cement/brine interactions (Bybee, 2010); and ( $\mathrm{v}$ ) assess rock strength after acid fracture treatment using $\mathrm{HCl}$ (Metcalf and Devine, 2004).

However, the chemicals used in most of the previous studies do not have the same chemistry as the chemical inhibitors commonly used in the oil and gas reservoirs, and consequently the corresponding results cannot be extrapolated to predict the effects of commonly used oilfield chemicals on the failure tendency of reservoir rocks. In addition, mechanical tests and mineral characterisation were not integrated to define failure mechanisms in the studies.

In the current work, the effect of corrosion inhibitor, scale inhibitor and biocide on the geomechanical strength of clastic and carbonate reservoir rocks are examined by integrating a number of laboratory tests (mechanical testing, grain size distribution analysis and analytical tests) to quantify the effects of these chemicals on sand failure.

\section{EXPERIMENTAL METHODS}

\subsection{Materials}

Aminotri (methylphosphonic acid) $\left(\mathrm{C}_{3} \mathrm{H}_{12} \mathrm{NO}_{9} \mathrm{P}_{3}\right)$ - (ATMP), glycine betaine $\left(\mathrm{C}_{5} \mathrm{H}_{11} \mathrm{NO}_{2}\right)$, glutaraldehyde $\left(\mathrm{C}_{5} \mathrm{H}_{8} \mathrm{O}_{2}\right)$, brine are the oilfield chemicals considered in this study. The choice of the chemicals were informed by the fact that they are commonly used in the oil and gas industry. Four (4) solid circular cylindrical core samples of sandstone obtained from an oil and gas well in the Niger Delta (Nigeria) and (five (5) solid circular cylindrical core samples of limestone obtained from Sokoto and Anambra Basins (Nigeria) were used in this study. The length, diameter, depth and locations of where the samples were obtained are presented in Table 1.

Table 1: Core sample geometrical parameters and location

\begin{tabular}{cccccc}
\hline Samples & L $(\mathbf{m m})$ & $\mathbf{D}(\mathbf{m m})$ & L/D & Depth $(\mathbf{f t})$ & Location \\
\hline SST-1 & 31 & 57 & 0.5 & $1946-1966$ & Niger Delta \\
SST-2 & 39 & 56 & 0.7 & $1946-1966$ & Niger Delta \\
SST-3 & 27 & 59 & 0.5 & $4009-4022$ & Niger Delta \\
SST-4 & 22 & 62 & 0.4 & $1580-1583$ & Niger Delta \\
LST-0 & 29 & 57 & 0.5 & $34-39$ & Sokoto Basin \\
LST-3 & 50 & 47 & 1.1 & 131 & Anambra Basin \\
LST-4 & 35 & 54 & 0.6 & $22-25$ & Sokoto Basin \\
LST-5 & 46 & 46 & 1.0 & 53 & Anambra Basin \\
LST-6 & 41 & 58 & 0.7 & $88-101$ & Sokoto Basin \\
\hline
\end{tabular}




\subsection{Pre and post chemical treatment tests}

\subsubsection{Mechanical test}

Uniaxial compression test (UCT) was conducted on the cylindrical core samples to measure the uniaxial compressive strength (UCS) of the intact rock. The test was performed based on the procedure recommended by the International Society for Rock Mechanics (ISRM) (Bieniawski and Bernede, 1979; ASTM 1991) using a screw-driven mechanical test machine Instron model 3382 that has a load capacity of $100 \mathrm{kN}$. The weight, length, and diameter of the cores were measured and recorded prior to the tests. The specimens (sandstone and limestone) were loaded in displacement control at a rate of $0.5 \mathrm{~mm} / \mathrm{min}$ until failure occurred. The load and the corresponding crosshead displacement were continuously recorded using the test machine in-built data logger.

The uniaxial compression test was carried out on both chemically treated and untreated samples. The samples were chemically treated as described in section 2.2.2. Oven dried chemically treated cores were used for post treatment mechanical testing. The purpose of the post chemical treatment mechanical testing was to evaluate any mechanical damage that may have taken place as a result of exposure to the chemicals under consideration.

Due to difficulty in obtaining rock samples from the Niger Delta (Nigeria), only one specimen was tested for each of the chemicals and rock types. However, to enhance reliability of results and remove effects of heterogeneity and fractures and other geological uncertainties, we ensured that the rock/cores used were homogeneous. In a separate study, core samples taken from the same reservoir and approximately same depth as those considered in the current paper have been shown to have porosity and permeability in the range of $24-29.5 \%$ and 379 $-613 \mathrm{mD}$ respectively for sandstone (Odoh et al., 2012) and that of limestone $10 \%-21 \%$ and $20 \mathrm{mD}-1400 \mathrm{mD}$ respectively (Uroro and Igharo, 2015).

\subsubsection{Static saturation}

The saturating fluids were prepared by diluting various salts in various concentrations with deionized water to obtain synthetic formation brine; the active elements in the brine are given in Table 2. The relative proportions of ion in the brine were chosen to simulate typical formation brine in the North Sea (Jordan and Sjursaether, 2005; Vazquez et al., 2016). The prepared brine was filtered through a $40 \mu \mathrm{m}$ sintered glass filter to remove any extraneous fines that may be present before use. Individual stock solutions of $1 \mathrm{wt} . \%$ betaine (corrosion inhibitor) and glutaraldehyde (biocide) were respectively prepared by diluting $2.5 \mathrm{~g}$ of each of the chemicals in $250 \mathrm{ml}$ of the prepared brine. Also, a stock solution of $5 \mathrm{wt} . \%$ scale inhibitor, (aminotri (methylene phosphonic acid) - ATMP) was prepared by diluting $12.50 \mathrm{~g}$ of the scale inhibitor in $250 \mathrm{ml}$ of the brine.

Four (4) sandstone and five (5) limestone samples were weighed and each of the sample was placed in a separate beaker and filled with one of the four different fluids - the brine, corrosion inhibitor, scale inhibitor and biocide - well enough to fully cover the core. The cores were allowed to remain in the fluids for one week to ensure complete saturation in line with the procedure reported by Oluyemi (2014). The cores were then removed from the fluids at the end of one week, rinsed with deionised water to prevent crystallisation of salt on the surface of the cores. The same deionised water was used to prepare the brine. The cores were dried in the oven at $135^{\circ} \mathrm{C}$ for three days with the weights checked on a daily basis by bringing them out of the oven, cooling them in air at room temperature, weighing and returning them to the oven until constant weights were obtained. The choice of the drying temperature was based on the recommendation by Tufail et al., (2017) and Lang et al., (2017). These works have 
suggested higher temperature than the standard $110 \pm 5^{\circ} \mathrm{C}$ to avoid under estimation of cation exchange capacity and specific surface area. Lang et al. (2017) recommended a temperature range between $150^{\circ} \mathrm{C}$ to $200^{\circ} \mathrm{C}$ for drying of bentonite. Quartz and limestone the dominant minerals in the samples can withstand higher temperature (Tufail et al., 2017). Saturation with brine was not carried out in this experiment due to limited sandstone sample.

Table 2: Brine composition

\begin{tabular}{lccccccccc}
\hline $\begin{array}{l}\text { Element } \\
\begin{array}{l}\text { Concentration } \\
(\mathrm{ppm})\end{array}\end{array}$ & $\mathrm{Na}^{+}$ & $\mathrm{K}^{+}$ & $\mathrm{Ca}^{2+}$ & $\mathrm{Mg}^{2+}$ & $\mathrm{Ba}^{2+}$ & $\mathrm{Sr}^{2+}$ & $\mathrm{Cl}^{-}$ & $\mathrm{SO}_{4}^{2-}$ & $\mathrm{HCO}_{3}^{2-}$ \\
\hline
\end{tabular}

\subsubsection{SEM, EDX and XRPD analysis}

Combined scanning electron microscope (SEM) and electron dispersive X-Ray (EDX) analysis of the treated and untreated rock core samples was carried out to identify and quantify the chemical changes that have taken place within the rock fabric which may form a basis for the potential mechanical damage to the rock fabric. Oven dried core samples were used for the SEM, EDX and XRPD analyses of the samples after the chemical treatment.

The SEM/EDX analysis was undertaken using a Zeiss EVO LS10 variable pressure scanning electron microscope. Samples were prepared by cutting them into nuggets, thoroughly degreased and dried to eliminate any outgassing from organic contamination and water before mounting on a stub for characterization.

Two types of test (bulk mineralogy and clay fraction) were carried out by means of X-Ray powder diffraction (XRPD) using identification and quantification of polycrystalline materials. Bulk samples were wet ground for 12 minutes in ethanol in a McCrone mill and sprayed dry to produce random powder specimens. X-ray powder diffraction (XRPD) patterns were recorded from $2-75^{\circ} 2 \theta$ using Cobalt $K \alpha$ radiation, counting for 2 seconds per $0.02^{\circ}$ step. Quantitative analysis was made by a normalised full pattern reference intensity ratio (RIR) method as described by Omotoso et al. (2006). Expanded uncertainty using a coverage factor of 2 , i.e. $95 \%$ confidence, was given by $X \pm 0.35$, where $X$ is the concentration in wt.\% (Hillier, 2002). The analysis was performed bearing in mind that for phases present at the trace level $(<1 \%)$ there may also be uncertainty as to whether or not the phase is truly present in the sample, since this is both phase and sample dependent.

The clay fractions of $<2 \mu \mathrm{m}$ were obtained by timed sedimentation, prepared as an oriented mount using the filter peel transfer technique and scanned from $2-45^{\circ} 2 \theta$ in the air-dried state, after glycolation, and after heating to $300{ }^{\circ} \mathrm{C}$ for one hour. The identified clay minerals were quantified using a mineral intensity factor approach based on calculated XRPD patterns. Unless otherwise stated, for the clay minerals present in amounts $>10 \mathrm{wt} . \%$ the uncertainty is estimated as better than $\pm 5 \mathrm{wt}$. $\%$ at the $95 \%$ confidence level.

\subsubsection{Particle size distribution}

The particle size distributions of the original brine and effluent samples that resulted from the static saturation were measured using a Malvern Laser Mastersizer 2000s. The effluents were stirred with magnetic stirrer and with the use of a $20 \mathrm{~mL}$ dropper, were subsequently fed into the Malvern Laser Mastersizer to ensure the entire range of particle sizes in the original brine and the effluents was adequately captured. The measured value of the effluents in volume percent (vol.\%) was converted to weight percent In order to determine the particle size distribution. 


\section{RESULTS AND DISCUSSION}

\subsection{Characterisation of sandstone and limestone}

The core samples were characterized using SEM, EDX and XRPD prior to chemical treatment to determine the morphology, element and mineral composition.

Sandstone was found to have well-sorted, sub-rounded quartz grains (Figure 1a). This is confirmed by EDX scan showing high traces of silicon and oxygen (Figure $1 \mathrm{~b}$ and Table 3 ). The presence of quartz mineral is further confirmed by the bulk mineralogy result under XRPD (Figure $1 \mathrm{c}$ and Table 5) with an increased proportion of quartz ( $83.3 \mathrm{wt} . \%$ ) and $16.7 \mathrm{wt. \%}$ of other minerals, such as K-feldspar, calcite, pyrite, halite, illite plus illite/smectite mixed layer $(I+I / S-M L)$ and kaolinite. Previous work (Etimita, 2015) reported similar mineral composition. Clay fraction identification shows the presence of chlorite (6 wt.\%) in untreated sandstone (Figure $1 \mathrm{~d}$ and Table 6).

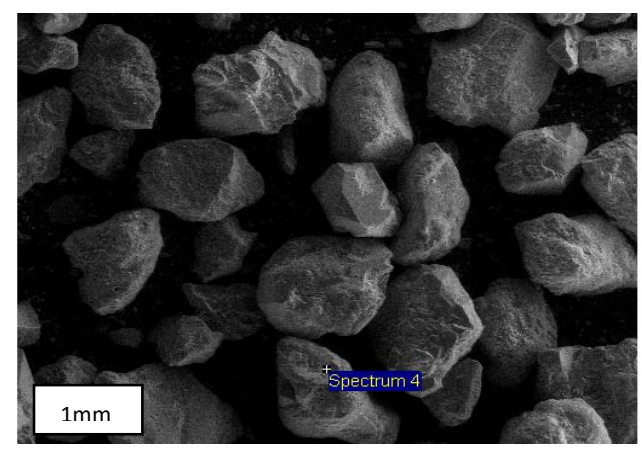

(a)

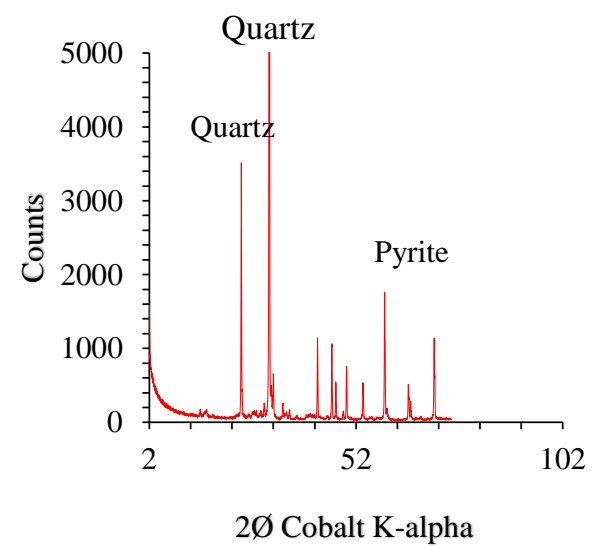

(c)

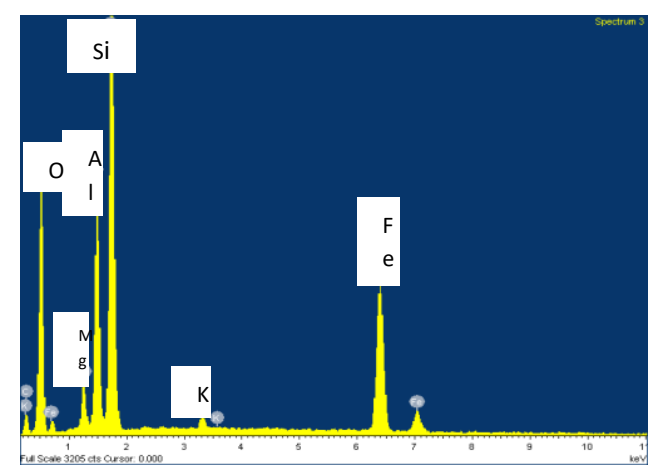

(b)

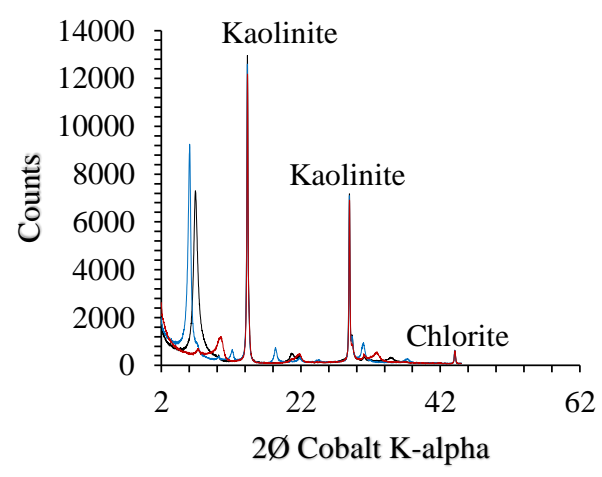

(d)

Figure 1: Characterisation of untreated sandstone: (a) SEM micrograph, (b) EDX scan, (c) XRPD bulk mineralogy, and (d) XRPD clay fraction identification. 
Table 3: Elemental composition of sandstone using SEM-EDX pre and post treatment with different chemicals.

\begin{tabular}{ccccc}
\hline Elements & $\begin{array}{c}\text { Pre- } \\
\text { treatment } \\
(\mathrm{wt} \%)\end{array}$ & $\begin{array}{c}\text { Betaine } \\
(\mathrm{wt} \%)\end{array}$ & $\begin{array}{c}\text { ATMP } \\
(\mathrm{wt} \%)\end{array}$ & $\begin{array}{c}\text { Glutaraldehyde } \\
(\mathrm{wt} \%\end{array}$ \\
\hline $\mathrm{Na}$ & $\mathrm{ND}$ & 0.5 & 1.3 & 0.7 \\
$\mathrm{Mg}$ & $\mathrm{ND}$ & 0.2 & 0.5 & 1.0 \\
$\mathrm{O}$ & 61.3 & 63.0 & 65.9 & 66.2 \\
$\mathrm{Al}$ & 0.6 & 2.9 & 2.8 & 4.3 \\
$\mathrm{Ag}$ & $\mathrm{ND}$ & $\mathrm{ND}$ & $\mathrm{ND}$ & 0.27 \\
$\mathrm{P}$ & $\mathrm{ND}$ & $\mathrm{ND}$ & 2.0 & $\mathrm{ND}$ \\
$\mathrm{Cl}$ & $\mathrm{ND}$ & 0.3 & 2.1 & 0.7 \\
$\mathrm{~K}$ & 0.1 & 1.1 & 0.2 & 0.4 \\
$\mathrm{Ca}$ & 0.1 & 4.5 & 0.1 & $\mathrm{ND}$ \\
$\mathrm{Fe}$ & 0.1 & 0.4 & 1.5 & 2.7 \\
$\mathrm{Ti}$ & $\mathrm{ND}$ & 0.3 & $\mathrm{ND}$ & 0.2 \\
$\mathrm{C}$ & 13.2 & 10.2 & 2.07 & $\mathrm{ND}$ \\
$\mathrm{Si}$ & 24.5 & 16.6 & 20.2 & 23.6 \\
$\mathrm{Total}$ & 100.0 & 100.0 & 98.7 & 100.0 \\
\hline \multicolumn{5}{c}{$\mathrm{ND}=\mathrm{NOT}$ DETECTED } \\
\hline
\end{tabular}

Similarly, the SEM micrograph of the limestone reveals poorly sorted, rhombohedral calcite minerals (Figure 2a) as confirmed by EDX scan showing high traces of calcium (Ca), Oxygen (O) and carbon (C), see Figure $2 \mathrm{~b}$ and Table 4. XRPD result further confirms the limestone consist of high proportion of calcite (78.6 wt\%) and $21.4 \mathrm{wt} \%$ of other minerals like dolomite, quartz, I+I/S-ML, kaolinite and palygorskite (Figure $2 \mathrm{c}$ and Table 5 ). The X-ray powder diffraction (XRPD) results for bulk mineralogy (whole rock analysis) shown in Figure $2 \mathrm{c}$ and Table 5 further reveal the presence of quartz, calcite, dolomite, $\mathrm{I}+\mathrm{I} / \mathrm{S}-\mathrm{ML}$, kaolinite and palygorsite in untreated, brine treated and ATMP treated limestone. Palygorskite was found in the limestone samples from Sokoto Basin, which is consistent with previous findings (Nton and Elueze, 2005). The presence of palygorskite (44\%), kaolinite (18\%), I/S-ML (37\%) and chlorite $(1 \%)$ in untreated limestone is revealed by clay fraction identification (Figure $2 \mathrm{~d}$ and Table 6 ). 


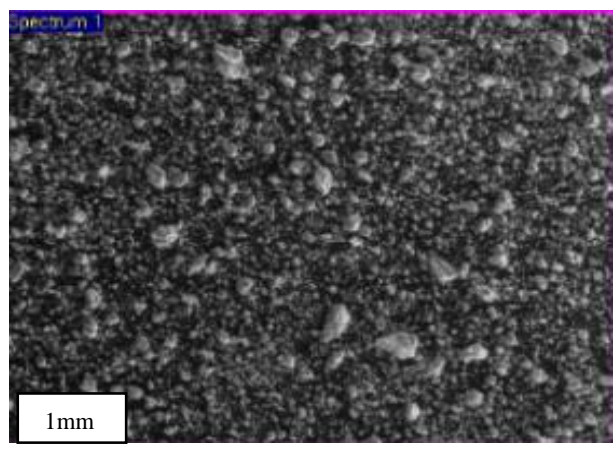

(a)

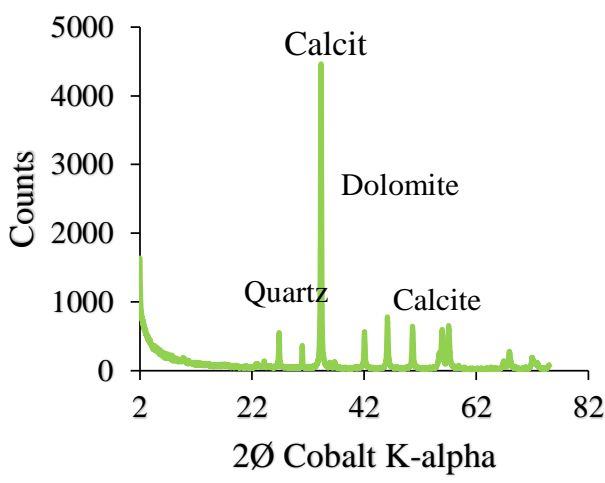

(c)

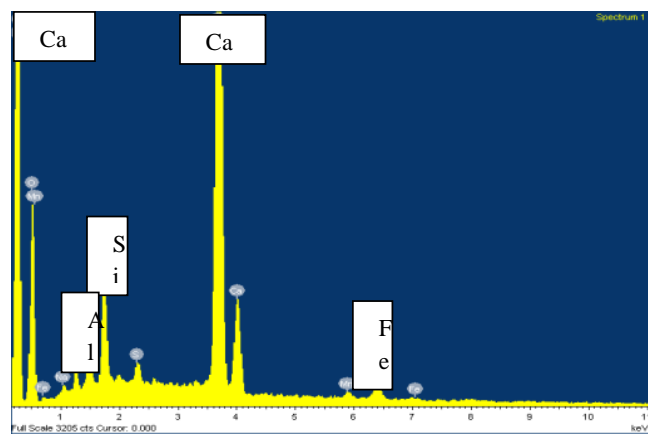

(b)

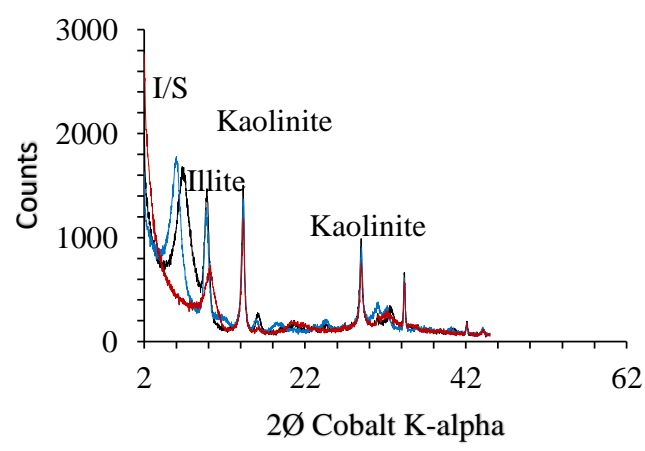

(d)

Figure 2: Characterisation of untreated limestone (a) SEM micrograph, (b) EDX scan, (c) XRPD bulk mineralogy and (d) XRPD clay fraction identification.

Table 4: Elemental composition of limestone using SEM-EDX pre and post treatment with different chemicals.

\begin{tabular}{|c|c|c|c|c|c|}
\hline Elements & $\begin{array}{c}\text { Pre- } \\
\text { treatment } \\
(\mathrm{wt} \%)\end{array}$ & $\begin{array}{l}\text { Brine } \\
(\mathrm{Wt} \%)\end{array}$ & $\begin{array}{l}\text { Betaine } \\
\text { (wt } \%)\end{array}$ & $\begin{array}{l}\text { ATMP } \\
(\mathrm{wt} \%)\end{array}$ & $\begin{array}{c}\text { Glutaraldehyde } \\
\text { (wt } \%)\end{array}$ \\
\hline $\mathrm{Na}$ & 0.93 & ND & 33.5 & ND & ND \\
\hline $\mathrm{C}$ & 18.8 & 25.5 & 10.0 & 13.8 & 13.8 \\
\hline $\mathrm{O}$ & 57.5 & 46.6 & 11.7 & 53.9 & 60.6 \\
\hline $\mathrm{Mg}$ & 1.8 & 0.4 & 0.6 & 0.4 & 0.3 \\
\hline $\mathrm{Al}$ & 4.9 & 1.0 & 1.0 & 2.0 & 0.5 \\
\hline $\mathrm{Si}$ & 0.1 & 2.9 & 4.0 & 0.3 & 0.4 \\
\hline S & 0.2 & 0.6 & ND & ND & ND \\
\hline Mn & 0.1 & 0.3 & ND & ND & ND \\
\hline $\mathrm{Fe}$ & 0.1 & 0.7 & 0.4 & 0.2 & 0.2 \\
\hline $\mathrm{Cl}$ & ND & ND & 35.8 & ND & 0.2 \\
\hline K & ND & ND & ND & ND & ND \\
\hline $\mathrm{Ca}$ & 13.9 & 20.4 & 3.1 & 29.4 & 24.2 \\
\hline Total & 98.4 & 98.4 & 100.0 & 100.0 & 100.0 \\
\hline
\end{tabular}


Table 5: XRPD Bulk Mineralogy (wt \%) based on reference intensity ratio (RIR) Method

\begin{tabular}{|c|c|c|c|c|c|c|c|c|c|c|c|c|c|c|}
\hline Sample ID & 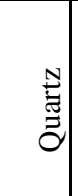 & 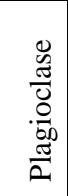 & $\begin{array}{l}\frac{\tilde{z}}{2} \\
\frac{0}{0} \\
\frac{0}{2} \\
\frac{0}{11}\end{array}$ & $\frac{\mathscr{0}}{\frac{0}{0}}$ & $\begin{array}{l}\stackrel{\mathscr{Z}}{\Xi} \\
\text { 응 } \\
\text { ค. }\end{array}$ & $\stackrel{\overbrace{}}{\stackrel{2}{二}}$ & 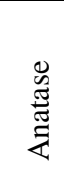 & 莺 & 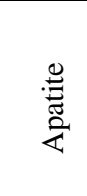 & \begin{tabular}{l}
$\sum_{1}$ \\
$\vdots$ \\
\multirow{2}{*}{} \\
$*$ \\
$*$
\end{tabular} & 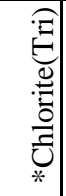 & 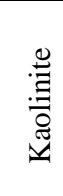 & 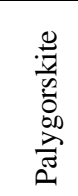 & 氶 \\
\hline SST-Untreated & 83.3 & 0.0 & 12.1 & 1.3 & 0.0 & 0.1 & 0.0 & 0.2 & 0.0 & 1.0 & 0.0 & 2.0 & 0.0 & 100.0 \\
\hline SST-Betaine & 62.9 & 0.3 & 14.8 & 13.2 & 0.0 & 0.4 & 0.1 & 0.1 & 0.0 & 2.5 & 1.5 & 4.2 & 0.0 & 100.0 \\
\hline SST-ATMP & 96.4 & 0.0 & 1.3 & 0.2 & 0.1 & 0.1 & 0.0 & 0.9 & 0.0 & trace & 0.4 & 0.6 & 0.0 & 100.0 \\
\hline SST-Glut & 96.8 & 0.5 & 1.2 & 0.1 & 0.6 & 0.0 & 0.0 & 0.1 & 0.0 & trace & 0.3 & 0.4 & 0.0 & 100.0 \\
\hline LST-Untreated & 3.9 & 0.0 & 0.0 & 78.6 & 2.4 & 0.0 & 0.0 & 0.0 & trace & 6.1 & 0.0 & 3.5 & 5.5 & 100.0 \\
\hline LST-Brine & 3.6 & 0.0 & 0.0 & 79.3 & 3.1 & 0.0 & 0.0 & 0.2 & trace & 4.9 & 0.0 & 3.2 & 5.7 & 100.0 \\
\hline LST-Betaine & 0.8 & 0.0 & 0.0 & 95.5 & 0.5 & 0.4 & 0.0 & 0.0 & 0.4 & 2.4 & 0.0 & 0.0 & 0.0 & 100.0 \\
\hline LST-ATMP & 1.6 & 0.0 & 0.0 & 79.5 & 0.0 & 0.1 & 0.0 & 0.5 & 0.0 & 5.1 & 0.0 & 0.0 & 13.2 & 100.0 \\
\hline LST-Glut & 2.1 & 0.0 & 0.0 & 91.1 & 0.9 & 0.3 & 0.0 & 0.0 & 0.0 & 4.4 & 0.0 & 1.2 & 0.0 & 100.0 \\
\hline
\end{tabular}

$*$ Chlorite $($ Tri $)=$ Trioctahedral Chlorite; $* *$ I+I/S-ML = Illite+Illite/Smectite - Mixed Layers

Table 6: Relative percentage of clay minerals in the $<2 \mu \mathrm{m}$ clay size fraction

\begin{tabular}{ccccccc}
\hline Sample ID & Chlorite & Kaolinite & Illite & I/S_ML & Palygorskite & \% Expandability \\
\hline $\begin{array}{c}\text { SST- } \\
\text { Untreated }\end{array}$ & 6 & 45 & 2 & 47 & 0 & 100 \\
SST-betaine & 7 & 33 & 2 & 58 & 0 & 100 \\
SST-ATMP & 27 & 40 & 4 & 29 & 0 & indeterminate \\
SST-Glut & 24 & 44 & 5 & 27 & 0 & indeterminate \\
$\begin{array}{c}\text { LST- } \\
\text { Untreated }\end{array}$ & 1 & 18 & 0 & 44 & 37 & 85 \\
LST-brine & 0 & 11 & 0 & 45 & 44 & 85 \\
LST-betaine & 0 & 4 & 0 & 96 & 0 & indeterminate \\
LST-ATMP & 0 & tr & 0 & 48 & 52 & 85 \\
LST-Glut & 0 & 11 & 0 & 89 & 0 & 85
\end{tabular}




\subsection{Effect of chemicals on geomechanical strength}

The pre and post chemical treatment uniaxial stress-strain responses in compression for the sandstone and limestone are shown in Figure 3. For both chemically treated (post) and untreated (pre) samples, the load increased linearly with increasing applied axial displacement (or strain) until failure of the sample or the load limit of the test machine was reached.

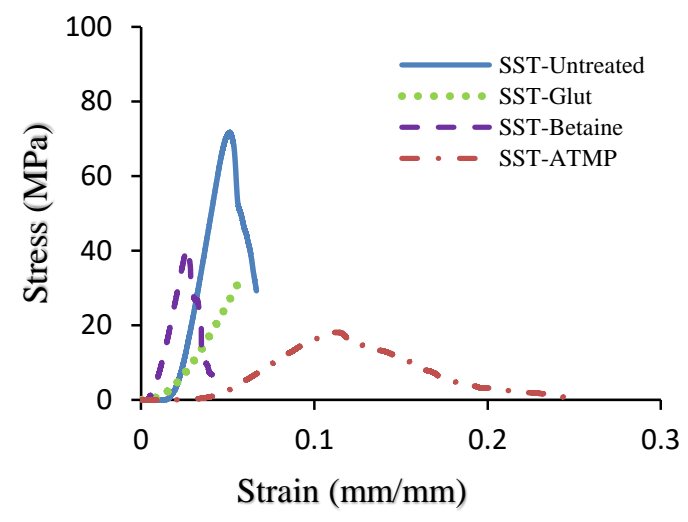

(a)

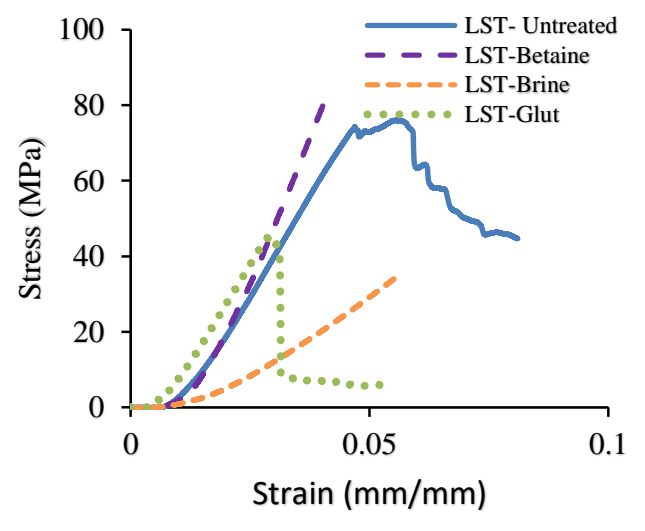

(b)

Figure 3: Uniaxial compression response pre-treatment and post chemical treatment of (a) sandstone and (b) limestone.

Acknowledging that the sample dimensions have influence on the strength, the measured strength of core samples with length/diameter (L/D) ratio less than 2 was corrected using the ASTM standard correction factor of 0.87 (ASTM, 1992). Table 7 shows the measured and corrected uniaxial compressive strength of untreated and treated sandstone. The strength of untreated sandstone reduced from $72 \mathrm{MPa}$ to 18,40 and $32 \mathrm{MPa}$ following treatment with scale inhibitor (ATMP), corrosion inhibitor (betaine), and biocide (glutaradehyde) respectively. For the limestone, the pre treatment strength reduced from $76 \mathrm{MPa}$ to approximately $45 \mathrm{MPa}$ as a result of treatment with glutaraldehyde (Table 7). There was no failure in the limestone treated with corrosion inhibitor (betaine) and brine when a load of $90 \mathrm{kN}$ was applied; this is equivalent to an axial stress of $54 \mathrm{MPa}$ and $80 \mathrm{MPa}$ respectively. Recall that the maximum load capacity of the test machine was $100 \mathrm{kN}$, so the test was stopped just before the limit was attained. Surprisingly, the limestone sample treated with the scale inhibitor (ATMP) cracked and split before the mechanical test possibly as a result of the interaction between the chemical and the sample (Figure 4). As the sample was obtained from a relatively shallow depth (22-25 ft), see Table 1, it is expected to have a relatively low initial compressive strength. Consequently, no compression test was conducted on the sample. A summary of the uniaxial compressive strength is given in Table 7 . These results showed a $55 \%$ and $41 \%$ reduction in strength for sandstone treated with ATMP and limestone treated with glutaraldehyde respectively, when compared with the corresponding untreated samples. 
Table 7: Summary of mechanical test results for sandstone and limestone

\begin{tabular}{|c|c|c|c|c|c|}
\hline Sandstone & $\begin{array}{l}\text { Pre- } \\
\text { Treatment }\end{array}$ & *Brine & ATMP & Betaine & **Glutaraldehyde \\
\hline Max. load (N) & 80,382 & N/A & 54,618 & 45,307 & 90,000 \\
\hline UCS (MPa) & 72 & N/A & 18 & 40 & 32 \\
\hline $\mathrm{L} / \mathrm{D}$ ratio & 0.7 & N/A & 0.4 & 0.5 & 0.5 \\
\hline UCS (MPa) using ASTM $(0.87)^{17}$ & 63 & N/A & 16 & 35 & 28 \\
\hline Limestone & $\begin{array}{c}\text { Pre- } \\
\text { Treatment }\end{array}$ & $* *$ Brine & ***ATMP & $* *$ Betaine & Glutaraldehyde \\
\hline Max. load (N) & 85,176 & 90,000 & N/A & 90,000 & 78,922 \\
\hline UCS (MPa) & 76 & $\geq 80$ & N/A & $\geq 54$ & 45 \\
\hline $\mathrm{L} / \mathrm{D}$ ratio & 0.7 & 0.5 & N/A & 1 & 1 \\
\hline UCS (MPa) using ASTM $(0.87)^{17}$ & 66 & 70 & N/A & 47 & 39 \\
\hline$* * *$ Specimen cra & $\begin{array}{l}* \text { Inst } \\
\text { No failure a } \\
\text { ed after chen }\end{array}$ & $\begin{array}{l}\text { fficient san } \\
\text { maximum } \\
\text { ical expost }\end{array}$ & $\begin{array}{l}\text { ple } \\
\text { oad of } 90 \mathrm{kl} \\
\text { re and befor }\end{array}$ & ompressio & \\
\hline
\end{tabular}

For the sandstone specimens exposed to brine, betaine and ATMP, failure occurred below the load capacity of the machine and it was therefore possible to compare the relative impact of the chemicals on the geomechanical strength of the formation rock. However, the limestone exposed to ATMP split before chemical testing indicating significant damage to the fabric due to the exposure, while the core exposed to glutaraldehyde was tested to failure. Ideally it would be preferable to have been able to test all the cores to failure. Nonetheless, the authors believe there is sufficient number of sandstone and limestone core samples tested to failure after exposure to different chemicals to provide adequate results for relevant comparison and meaningful conclusions.

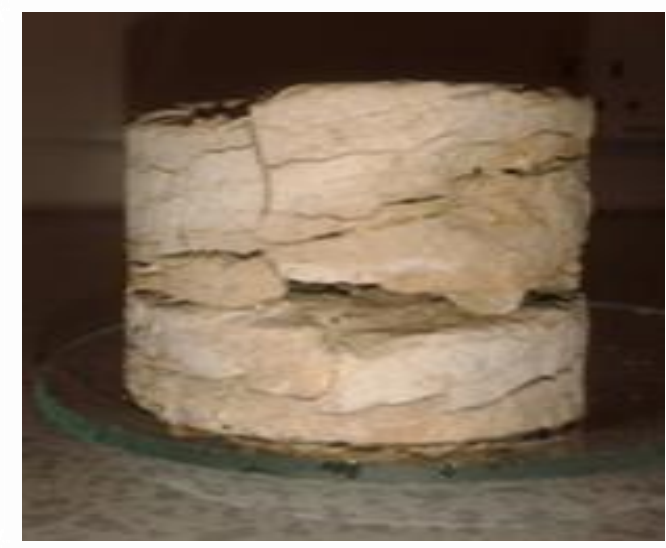

Figure 4: Damaged limestone due to treatment with ATMP.

The significant effect of the chemical treatment on the limestone, especially with ATMP, compared to the sandstone is attributed to a more rapid deterioration of grain to grain binding in the limestone. Sandstone due to its high porosity in nature absorbs fluids more and faster, however, it does not retain the fluids compared to limestone. As such the interaction between the chemicals and the limestone as made possible by adsorption would have resulted in the 
weakening of the materials that bind the grains together leading to significant reduction in the compressive strength.

\subsection{Failure effects on sandstone}

Changes, if any, in the mineralogical and elemental composition of sandstone as a result of interaction with the chemicals were investigated.

The SEM micrographs, EDX and XRPD analysis of a sandstone sample post exposure to betaine are shown in Figure 5 . The post treatment SEM micrographs for the sandstone sample (Figure $5 a)$ reveals the spreading of the altered mineral constituents on the surface of the larger unaltered quartz grains as indicated by the arrow in contrast to the untreated samples which consists primarily of unaltered quartz grains (Figure 1a). This observation is consistent with that of chalk when exposed to brine as reported by Madland et al. (2011). Also noted is a clear evidence of loose grain assemblages which resulted from the disintegration of the mineral constituent of the cores. The interaction of the chemicals with the rock materials contributed to the weakening of the grain fabrics of the core, resulting in the disintegration of the grainto-grain binding and eventual loosening and migration of sand grain (Oluyemi, 2014). Additionally, the presence of pitting in the SEM micrograph circled in Figure $5 b$ which would have been made possible by the reaction of the chemicals with the feldspar is an evidence that dissolution/precipitation of certain minerals took place (Allen and Conca, 1991; Jordan et al., 1994). The elemental composition of sandstone samples after chemical treatment as obtained from the EDX analysis is included in Table 3 and Figure 5c.

On the other hand, the X-ray powder diffraction (XRPD) results for bulk mineralogical (whole rock) analysis, (Table 5 and Figure $5 \mathrm{~d}$ ), reveal quartz, plagioclase (albite), K-feldspar, pyrite, $\mathrm{I}+\mathrm{I} / \mathrm{S}-\mathrm{ML}$, chlorite, calcite and kaolinite in the sandstone treated with betaine; quartz, Kfeldspar, calcite, dolomite, halite, chlorite and kaolinite in the sandstone treated with ATMP; and quartz, plagioclase, K-feldspar, calcite, dolomite, halite, chlorite and kaolinite in sandstone treated with glutaraldehyde. Quartz which is the dominant mineral in the sandstone core sample is believed to be non-reactive in the presence of acidic inhibitor species, hence, may not undergo dissolution (Jordan et al., 1994). However, in this study, quartz is observed to have reduced from $83.3 \mathrm{wt} . \%$ to $62.9 \mathrm{wt} . \%$ in the presence of betaine and yet increased to slightly $96.4 \mathrm{wt} . \%$ and $96.8 \mathrm{wt} . \%$ in the presence of ATMP and glutaraldehyde respectively. The change would have been made possible by the reaction that occurs through hydrolysis which causes "surface energy and cohesion reduction" (Han and Dusseault, 2002). As a result of this reaction, more K-feldspar and calcite precipitated. The dissolution of quartz in the presence of betaine and the precipitation of quartz in the presence of ATMP and glutaraldehyde which would have occurred through diagenesis is consistent with previous work (Yang et al., 2017). 


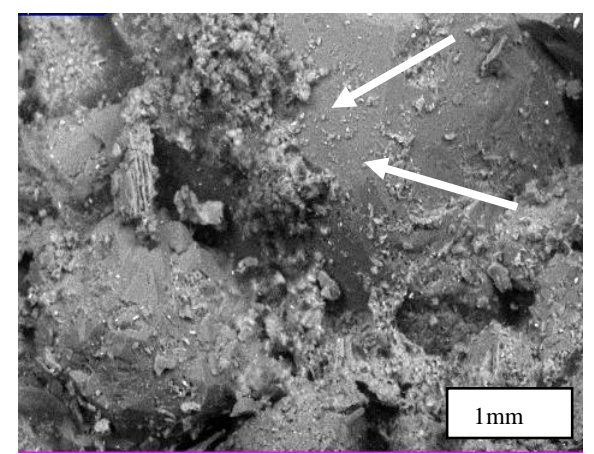

(a)

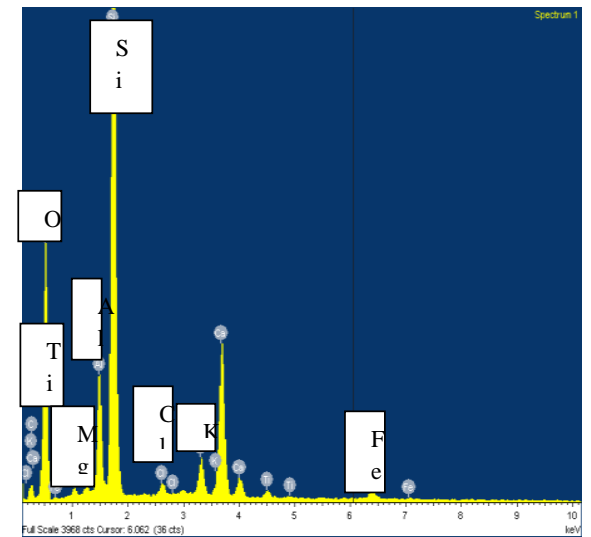

(c)

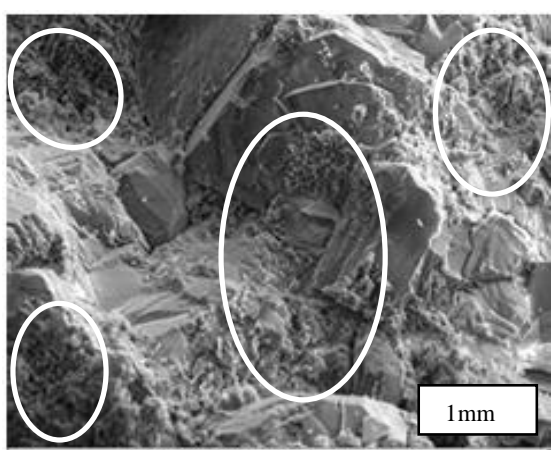

(b)

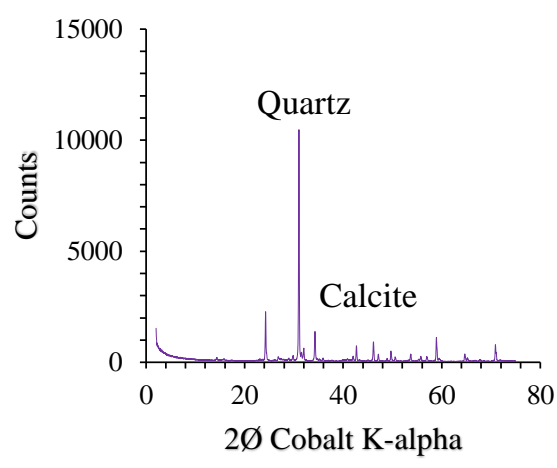

(d)

Figure 5: The SEM micrograph of sandstone post saturation with betaine showing (a) the spread of altered minerals on unaltered grain, and, (b) Pitting; and the associated: (c) XRPD bulk mineralogy scan and (d) EDX scan.

The observed increase in the composition of calcite due to exposure of the sandstone to betaine and increase in quartz concentration due to exposure to ATMP and glutaraldehyde are consistent with the likely reactions which are presented in equations 1 to 3 :

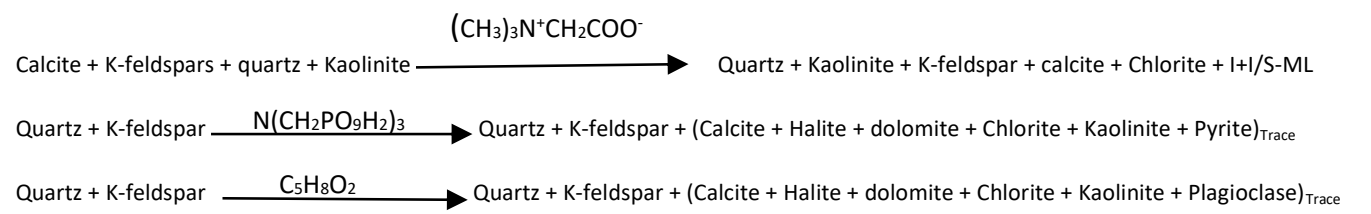

Clay mineral identification reveals a substantial increase of chlorite from $6 \%$ to $27 \%$ and $24 \%$ when the sandstone was exposed to ATMP and glutaraldehyde respectively, but with little or no change when treated with betaine, see Table 6 . Kaolinite ( $45 \%$ in untreated sandstone) reduced to $33 \%$ and $40 \%$ owing to treatment with betaine and ATMP respectively. Illite increased slightly from $2 \%$ to $4 \%$ and $5 \%$ with ATMP and glutaraldehyde respectively, whilst, the mixed-layered illite/smectite that approached pure smectite with $100 \%$ expandability in the untreated sandstone changed from $47 \%$ to $58 \%, 29 \%$ and $27 \%$ following treatment with betaine, ATMP and glutaraldehyde respectively. It is worthy of note that the absence of brine exposure due to insufficient number of core sample, which could have served as control 
makes it difficult to confirm that the changes observed in sandstone are entirely due to the chemicals interaction with the rock and not an effect of the combined interaction of the chemical and the brine with the rock.

The studied sandstone core sample is identified to have high content of clay minerals (Table 6). Clay minerals in their nature are very reactive due to their large surface area and negative charge. The dissolution of feldspar and the clay minerals (kaolinite, chlorite, illite and illite/smectite) can lead to precipitation of other clay minerals as evidenced by clay fraction results (Marty et al., 2015; Shao et al., 2010); and the hydrolysis of quartz due to chemicalformation rock interaction can cause reduction of the geomechanical strength of the reservoir rock (Han and Dusseault, 2002). The weakening effect of the chemical on the rock cement was more evident in betaine treated sandstone.

\subsection{Failure effects on limestone}

Figure 6 shows the SEM micrograph, and EDX and XRPD scans of the limestone after chemical treatment. Flaking of mineral grains and pitting are observed on the SEM micrograph of the treated limestone (Figure 6a). The SEM-EDX results (Figure $6 \mathrm{~b}$ and Table 4) show an increase of calcium (Ca) from 13.9 wt\% for untreated limestone to 20.4 wt $\%, 29.4$ wt $\%$ and 24.2 wt $\%$ when treated with brine, ATMP and glutaraldehyde respectively. Nevertheless, a significant reduction to $3.1 \mathrm{wt} \%$ is observed with the betaine treated limestone. The significant reduction is an indication that calcium was consumed in the reaction after dissolution to precipitate a new compound. Aluminium (AI) is reduced from $4.9 \mathrm{wt} \%$ to $(1,1,2$ and 0.5$) \mathrm{wt} \%$ following treatment with brine, betaine, ATMP and glutaraldehyde respectively. Silicon (Si) on the other hand, increased from $0.1 \mathrm{wt} \%$ to $2.9 \mathrm{wt} \%$ and $4 \mathrm{wt} \%$ respectively in the brine and betaine treated samples. Interestingly, there is a high content of sodium ( $\mathrm{Na}), 33.5 \mathrm{wt} \%$ and chloride (Cl), $35.8 \mathrm{wt} \%$ in betaine treated limestone with no presence of chloride in the untreated and other chemically treated limestone, despite that all the chemicals were prepared with brine that contains sodium chloride. The untreated limestone contains only $0.93 \mathrm{wt} \%$ of sodium. This could be a consequence of a new compound, for example sodium chloride $(\mathrm{NaCl})$, being formed and a clear evidence of elemental/ionic exchange between the limestone and the chemicals to varying degrees, especially betaine (Table 4). 


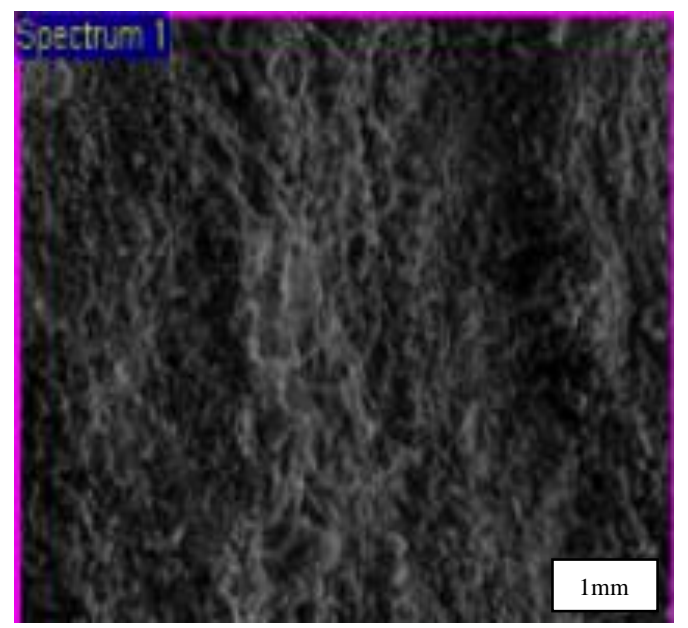

(a)

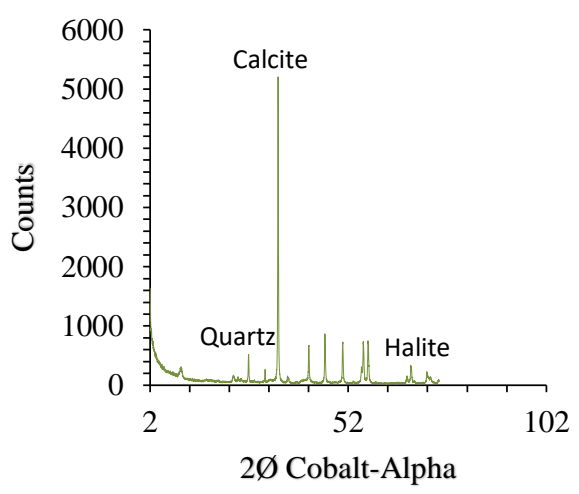

(c)

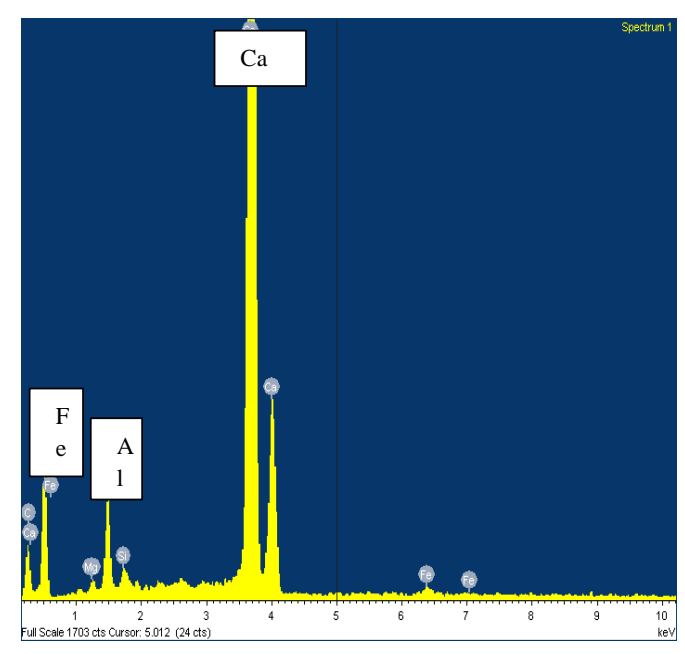

(b)

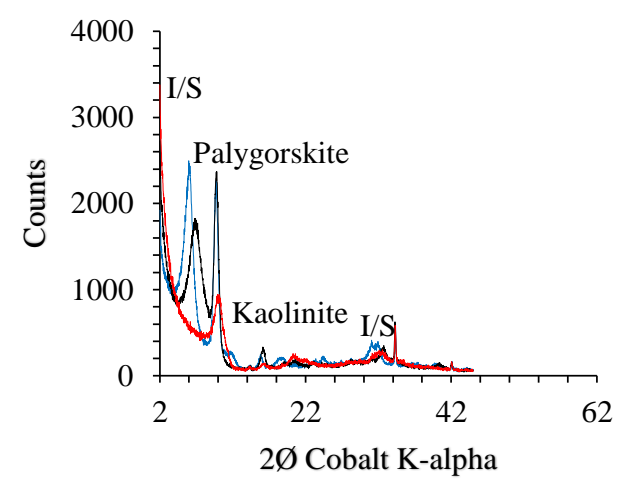

(d)

Figure 6: (a) The SEM micrograph of limestone post saturation with betaine showing the spreading of altered minerals on unaltered grain, (b) EDX scan; (c) XRPD bulk mineralogy and (d) XRPD pattern clay minerals in the $<2 \mu$ m clay size fraction.

The X-ray powder diffraction (XRPD) result for bulk mineralogical (whole rock) analysis shown in Figure $6 \mathrm{c}$ and Table 5 further confirms the exchange of elements between the rock cores and the chemicals to precipitate new minerals (Equations 4-7). Calcite increased from 78.6 wt\% to $95.5 \mathrm{wt} \%$ and $91.1 \mathrm{wt} \%$ in the presence of betaine and glutaraldehyde respectively, with little or no change in the presence of brine and ATMP. However, palygorsite $\left[(\mathrm{Mg}, \mathrm{Al}) 2 \mathrm{Si}_{4} \mathrm{O}_{10}(\mathrm{OH}) .4\left(\mathrm{H}_{2} \mathrm{O}\right)\right]$ increased significantly from $5.5 \mathrm{wt} \%$ (untreated) to $13.2 \mathrm{wt} \%$ with ATMP treated, however, it is completely absent in the betaine and glutaraldehyde treated limestone.

The observed increase in the concentration of calcite and palygorskite can be explained by the likely chemical reactions between the two samples (limestone) and the chemical inhibitors. This is based on the high percentage of observed elements in Tables 4 . The chemical reactions are further summarised in Table 8. 


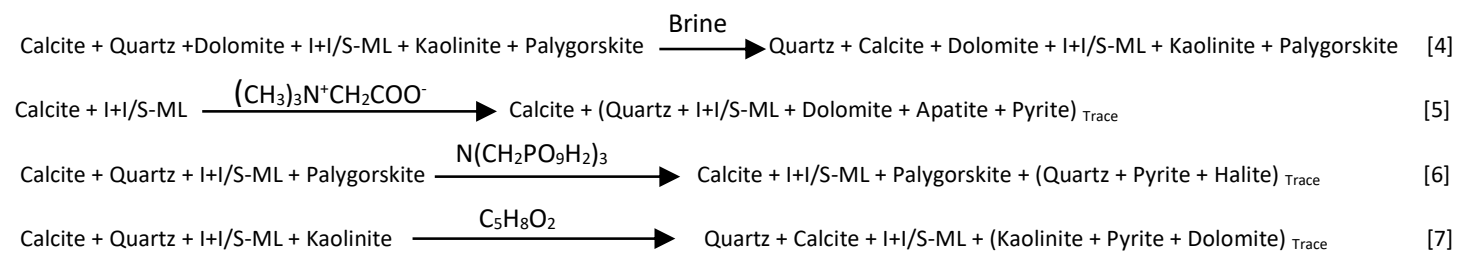

Table 8: Interactions between oilfield chemicals and formation rocks

\begin{tabular}{|c|c|}
\hline Reactions & Products \\
\hline \multirow{5}{*}{ Betaine $\left(\mathrm{C}_{5} \mathrm{H}_{11} \mathrm{NO}_{2}\right)$ and sandstone $\left(\mathrm{SiO}_{2}\right)$} & Chlorite \\
\hline & Quartz \\
\hline & K-Feldspar \\
\hline & Calcite \\
\hline & $\mathrm{I}+\mathrm{I} / \mathrm{S}-\mathrm{ML}$ \\
\hline $\operatorname{ATMP}\left(\mathrm{N}\left(\mathrm{CH}_{2} \mathrm{PO}_{9} \mathrm{H}_{2}\right)_{3}\right)$ and sandstone $\left(\mathrm{SiO}_{2}\right)$ & Quartz \\
\hline Gltaraldehyde $\left(\mathrm{C}_{5} \mathrm{H}_{8} \mathrm{O}_{2}\right)$ and sandstone $\left(\mathrm{SiO}_{2}\right)$ & Quartz \\
\hline \multirow[t]{3}{*}{$\operatorname{ATMP}\left(\mathrm{N}\left(\mathrm{CH}_{2} \mathrm{PO}_{9} \mathrm{H}_{2}\right)_{3}\right)$ and limestone $\left(\mathrm{CaCO}_{3}\right)$} & Calcite \\
\hline & Palygorskite \\
\hline & $\mathrm{I}+\mathrm{I} / \mathrm{S}-\mathrm{ML}$ \\
\hline \multirow{3}{*}{ Betaine $\left(\mathrm{C}_{5} \mathrm{H}_{11} \mathrm{NO}_{2}\right)$ and limestone $\left(\mathrm{CaCO}_{3}\right)$} & Calcite \\
\hline & $\mathrm{I}+\mathrm{I} / \mathrm{S}-\mathrm{ML}$ \\
\hline & $\begin{array}{l}\text { (quartz, dolomite, apatite, pyrite) - } \\
\text { trace }\end{array}$ \\
\hline \multirow{4}{*}{$\begin{array}{l}\text { Glutaraldehyde }\left(\mathrm{C}_{5} \mathrm{H}_{11} \mathrm{NO}_{2}\right) \text { and limestone } \\
\qquad\left(\mathrm{CaCO}_{3}\right)\end{array}$} & \\
\hline & Calcite \\
\hline & $\mathrm{I}+\mathrm{I} / \mathrm{S}-\mathrm{ML}$ \\
\hline & $\begin{array}{l}\text { (Kaolinite, dolomite, apatite, pyrite) - } \\
\text { trace }\end{array}$ \\
\hline
\end{tabular}

The XRPD for clay fraction identification (Figures $6 \mathrm{~d}$ ) shows the peak of palygorskite, kaolinite and I/S-ML in betaine treated limestone. Apart from kaolinite whose amount in the untreated limestone decreased from $18 \%$ to $11 \%, 4 \%$, trace and $11 \%$ in brine, betaine, ATMP and glutaraldehyde treated limestone respectively, the other clay minerals such as: I/S-ML increased from $44 \%$ in untreated limestone to $98 \%, 48 \%$ and $89 \%$ with betaine, ATMP and glutaraldehyde treated limestone respectively; and palygorskite increased from $37 \%$ to $44 \%$ and $52 \%$ in the presence of brine and ATMP respectively. However, no change of I/S content is observed with brine treated limestone. This is an evidence that the changes observed in the two rock types were brought about primarily by the interaction with the chemicals, and brine has little or no effect on the rock. This observation does not support the findings from previous work (Bybee, 2010; Madland et al., 2011).

The results clearly indicate moderate to high content of clay minerals in both sandstone and limestone samples whose expansion as demonstrated by the increase in expandability (Table 6) might have negatively impacted the rock strength owing to clay mechanical strength being generally weaker than a typical sandstone (Balog et al., 2014). It has been shown that amphoteric betaine adsorption in the presence of divalent ions is significantly higher on sandstone, in contrast to the adsorption on limestone (Mannhardt et al., 1993). The results obtained in the current study indicate adsorption, dissolution/precipitation and ionic substitution reaction of the oilfield chemicals with both sandstone and limestone. 


\subsection{Grain size distribution}

The grain size distribution profiles of the original brine and brine effluent as well as the effluents from the various chemical solutions are shown in Figure 7. Figure 7a shows that there was a notable difference in the key grain size parameters of D10, D50, D90 and sorting (also see Table 9) between the grain size distribution profiles of the original brine and the brine effluents from the two cores (sandstone and limestone). This is consistent with the visual observation of the presence of some particles in the effluents. The values of the key grain size parameters for the brine effluents suggest the particles originated either from the existing fines (D10) in the cores prior to saturation in the brine or from the fines that were less than the glass filter openings not filtered out by the glass filter. Integration of these results with the mechanical and analytical test results shows that there was no failure in the brine-treated cores and, therefore, no significant release of particles into the brine during the test. However, the difference in the grain size parameters between the original brine and all the chemical effluents was much more significant (see Fig. 7b, c; and Table 9). In particular, the chemical effluents appear to exhibit a broader grain distribution profile with poorer sorting in comparison to the original brine (Folk, 1966). Figures 6 shows that there was a release of some particles into the various chemical solutions during the tests. Similarly, integration of these results with the mechanical and analytical test results indicates failure of the chemically treated cores, which led to release of a wide range of particles into the chemical solutions. Increased proportion of particles in the effluent is implicitly caused by weakening of the rocks with a consequential reduction of their uniaxial compressive strength and release of failed materials into the flow streams. It is worthy of note, however, that it is possible for weakening of the bonding to occur without fine particles being released. In addition, presence of fines in effluent does not necessarily mean the fines are from inside the core as they could be from the near outer surface of the core. This is likely to occur from a low porosity and low permeability cores. Based on the SEM micrographs, the authors believe that the fines obtained in this study were primarily from the inside of the cores. Aside from the risk of the sand production that is associated with the interaction between the oilfield chemicals and the rock, there is also the risk of low reservoir performance and formation damage near wellbore due to pore space clogging by the released particles into the fluid stream, as evidenced by Figure $7 b, c$. 


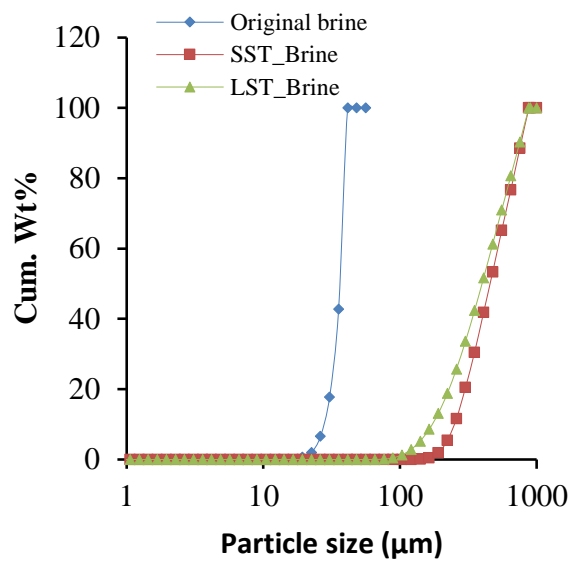

(a)

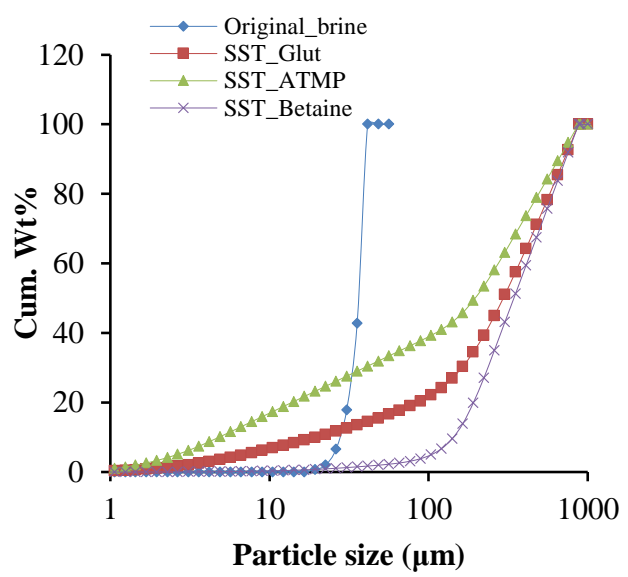

(b)

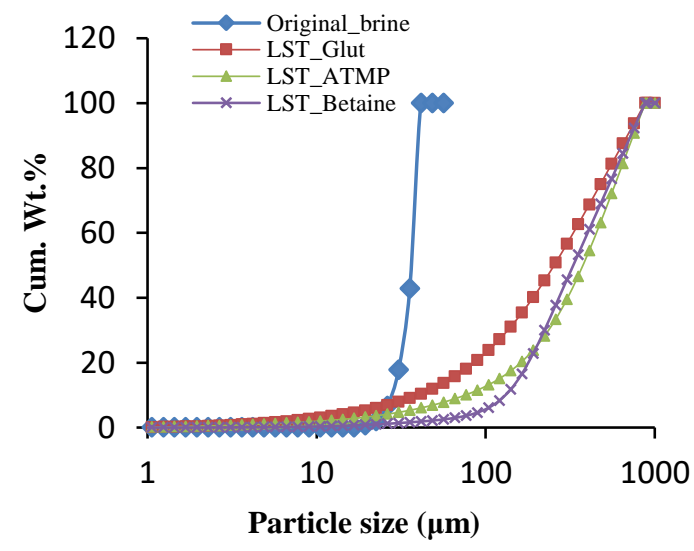

(c)

Figure 7: Comparison of the particle size distribution of the original brine and of (a) the effluents of sandstone and limestone in the brine; (b) the original brine and effluents from sandstone in betaine, ATMP and glutaraldehyde; (c) the original brine and effluents from limestone in glutaraldehyde, ATMP and betaine. 
Table 9: Grain size distributions of the original brine and the effluents

\begin{tabular}{|c|c|c|c|c|c|}
\hline & $\begin{array}{l}\text { Size } \\
\qquad \begin{array}{l}\text { D10 } \\
(\mu \mathrm{m})\end{array}\end{array}$ & $\begin{array}{l}\mathrm{D} 50 \\
(\mu \mathrm{m}) \\
\end{array}$ & $\begin{array}{l}\mathrm{D} 90 \\
(\mu \mathrm{m})\end{array}$ & Sortings ( $\sigma 1)$ & Classification (Folk 1966) \\
\hline Original brine & 26 & 40 & 41 & 0.36 & Well sorted \\
\hline Sandstone in brine & 4.5 & 74 & 409 & 0.83 & Moderately sorted \\
\hline $\begin{array}{l}\text { Limestone in brine } \\
\text { Sandstone in }\end{array}$ & 4.5 & 74 & 4.9 & 0.64 & Moderately well sorted \\
\hline $\begin{array}{l}\text { glutaraldehyde } \\
\text { Limestone in }\end{array}$ & 21 & 340 & 650 & 2.75 & Poorly sorted \\
\hline glutaraldehyde & 76 & 258 & 659 & 0.90 & Very poorly sorted \\
\hline Sandstone in ATMP & 5 & 349 & 700 & 2.10 & Very poorly sorted \\
\hline Limestone in ATMP & 76 & 350 & 800 & 1.23 & Poorly sorted \\
\hline Sandstone in betaine & 141 & 350 & 750 & 0.94 & Moderately sorted \\
\hline Limestone in betaine & 120 & 350 & 754 & 1.43 & Moderately sorted \\
\hline
\end{tabular}

There was clear evidence that a substantial amount of sand particles was introduced into the fluids that contain the chemicals during the static saturation as a result of the weakening of the cores grain fabrics causing disintegration of the existing grain-to-grain binding which could lead to eventual failure.

\section{Conclusions}

Interaction between reservoir formation rocks and three chemicals (biocide, corrosion inhibitor and scale inhibitor) which are commonly used in the oilfield for remedial treatment of reservoir formation has been investigated. Clastic and carbonate reservoir formation cores obtained from the Niger Delta were used in the study. Both mechanical and analytical tests were deployed to characterize the cores prior to and after chemical treatments to analyse the interaction between the chemicals and the cores. The results suggest that chemical interactions, adsorption, dissolution/precipitation and ionic substitution took place between the oilfield chemicals and the reservoir rocks which weakened the grain fabrics of the rocks and caused a release of disintegrated grains into the fluid streams. It can be observed from the results that betaine exhibited higher interaction with both sandstone and limestone than ATMP and glutaraldehyde with glutaraldehyde having the least effect on both rock types.

It is imperative that field operators take into cognizance the potential for dissolution and precipitation reaction between the materials (quartz and calcite) that cement the grains of sandstone and limestone and oilfield chemicals. Dissolution reaction can lead to the weakening of the rock fabric whilst precipitation may result in the formation of new materials which are weaker than the original rock materials. It is therefore recommended that the interaction between these chemicals and formation rock should be factored into the evaluation of failure and sand production potential for the field operation especially when extensive chemical injection programme is planned for such fields.

\section{Acknowledgement}

The authors gratefully acknowledge Petroleum Technology Development Fund (PTDF) Nigeria for funding the PhD work from which the materials and results presented in this paper originated. 


\section{References}

Allen, C.C. and Conca, J.L., 1991. Weathering of basaltic rocks under cold, arid conditionsAntarctica and Mars. In Lunar and Planetary Science Conference proceedings, 21, 711-717.

ASTM, 1991. Test method for obtaining and testing drilled cores and sawed beams of concrete, ASTM, U.S.A., 1992, C 42-90.

ASTM, 1992. C 42-90. Standard Test Method for Obtaining and Testing Method for obtaining and Testing Drilled cores and Sawed Beams of Concrete. 1991 Annual Book of ASTM Standards, Concrete and Aggregates, 4.

Balog, A., Cobirzan, N. and Barbu-Tudoran, L., 2014. Evaluation of limestone with non-invasive analytical methods. Romanian Journal of Physics, 59(5-6), 601-607.

Bieniawski, Z. and Bernede, M., 1979. Suggested methods for determining the uniaxial compressive strength and deformability of rock materials: Part 1. Suggested method for determining deformability of rock materials in uniaxial compression. Int. J. of Rock Mech. and Min. Sci. \& Geomech. Abstracts. 16 (02), 138-140.

Bybee, K., 2010. Two-Phase Cement/CO2/Brine Interaction in Wellbore Environments. J. of Pet. Tech., 62(05), 78-80.

Denney, D., 2013. Simulating the Chemical Interaction of Injected CO2 and Carbonic Acid. J. of Pet. Tech., 65(7), 125-127

Egermann, P., Bekri, S. and Vizika, O., 2010. An integrated approach to assess the petrophysical properties of rocks altered by rock-fluid interactions (CO2 injection). Petrophysics, 51(1), 32-40.

Etimita, O. O., 2015. Reservoir characterization of "G900" Sandstones using wireline Logs and cores in development planning of Gabo field, Onshore Niger Delta. IOSR J. Appl. Geol. and Geoph. 3, (6) 46-52.

Folk, R.L., 1966. A review of grain-size parameters. Sedimentology, 6(2), 73-93.

Han, G. and Dusseault, M., 2002. Quantitative analysis of mechanisms for water-related sand production. Paper 73737, presented at the SPE International Symposium and Exhibition on Formation Damage Control. Lafayette, Louisiana, 20-21 February.

Hillier, S., 2002. Quantitative analysis of clay and other minerals in sandstones by X-ray powder diffraction (XRPD). Clay Mineral Cements in Sandstones: Special Publication, 34, 213251.

Jordan, M.M., Sjursaether, K., 2005. Scale control within sea chalk/limestone reservoirs. The challenge of understanding and optimizing chemical placement methods and retention mechanism: laboratory to field. SPE 86476. Paper Presented at the SPE International Symposium and Exhibition on Formation Damage Control, Lafayette, Louisiana, USA. 18-20 February. 
Jordan, M., Sorbie, K., Ping, J., Yuan, M.D., Todd, A. and Hourston, K., 1994. Phosphonate Scale Inhibitor Adsorption/Desorption and the Potential for Formation Damage in Reconditioned Field Core. SPE Formation Damage Control Symposium. Society of Petroleum Engineers.

Lang, L. Xiang, W., Huang, W., Schanz, T., 2017. An Experimental study on oven-drying methods for laboratory determination of water content of a carbon-rich bentonite. Applied Clay Science, 150, 153-162.

Madland, M., Hiorth, A., Omdal, E. and Megawati, M. 2011. Chemical alterations induced by rock-fluid interactions when injecting brines in high porosity chalks. Transport in Porous Media, 87(3), 679-702.

Mannhardt, K., Schramm, L.L. and Novosad, J.J., 1993. Effect of rock type and brine composition on adsorption of two foam-forming surfactants. SPE Adv. Tech. Series, 1(1), 212218.

Marty N., Claret F., Lassin A., Tremosa J. and Blanc P., 2015. A database of dissolution and precipitation rates for clay-rocks minerals. Appl. Geochem. 55, 108-118.

Metcalf, A. and Devine, C., 2004. Evaluation of interaction of acid systems and formation samples improves production response. J. of Canadian Pet. Tech., 43(5), 49-56.

Mohamed, I. and Nasr-El-Din, H.A., 2013. Fluid/rock interactions during CO2 sequestration in deep saline carbonate aquifers: laboratory and modelling studies. SPE Journal, 18(03), 468485 .

Nton, M. and Elueze, A.A., 2005. Compositional characteristics and industrial assessment of sedimentary clay bodies in part of eastern Dahomey Basin, southwestern Nigeria. J. of Min. and Geol., 41(2), 175-184.

Odoh B.I., Onyeji J., Utom A.U., 2012. The integrated seismic reservoir characterization (ISRC), study in Amboy field of Niger Delta oil field-Nigeria. Geosciences 2(3):60-65.

Oluyemi, G., 2014. Conceptual Physicochemical Models for Scale Inhibitor-Formation Rock Interaction. Pet. Sci. and Tech., 32(3), 253-260.

Oluyemi, G.F., Oyeneyin, B.M. and Macleod, C., 2010. UCS neural network model for real time sand prediction. Int. J. of Eng. Res. in Africa. 2, 1-13.

Omotoso, O., D. K. Mccarty, S. Hillier, and R. Kleeberg, 2006. Some successful approaches to quantitative mineral analysis as revealed by the 3rd Reynolds Cup contest: Clays and Clay Minerals. 54 (6), 748-760.

Oyeneyin, M.B., Macleod, C., Oluyemi, G. and Onukwu, A., 2005. Intelligent Sand Management. In: Proceedings of Nigeria Annual International Conference and Exhibition, Abuja, Nigeria, August 1 - 3. 
Shao, H., Ray, J., and Jun, Y-S., 2010. Dissolution and precipitation of clay minerals under geologic $\mathrm{CO}_{2}$ sequestration conditions: $\mathrm{CO}_{2}$-brine-phlogopite interactions, Environ. Sci. Technol., 44(15), 5999-6005.

Tomson, M.B., Kan, A.T., Fu, G., Shen, D., Nasr-El-Din, H.A., Saiari, H.A. and Al Thubaiti, M.M., 2008. Mechanistic Understanding of Rock/Phosphonate Interactions and Effect of Metal lons on Inhibitor Retention. SPE Journal. 13(03), 325-336.

Tufail, M., Shahzada, K., Gencturk, B., 2107. Effect of elevated Temperature on mechanical properties of limestone, quartzite and granite concrete. Int. J. of Concrete Structures and Materials. 11, 17-28.

Uroro, E. and Igharo, E., 2015. Organic geochemical characterization of "L-1" well in the Anambra Basin, Southern Nigeria for source rock and hydrocarbon potential. Int. jour. of Sci. and Eng. 8(1), 47-53.

Vazquez, O., Herrero, P., Mackay, E.J., Jordan, M., 2016. Non-aqueous overflush scale inhibitor squeeze treatment in an oilfield offshore Norway. Journal of Petroleum Science and Engineering, 138, 1-10.

Wilson, A., 2016. Chemical Analysis of flowback water and downhole gas-shale samples. J. of Pet. Tech., 68(09), 114-115.

Yang, L., Xu, T., Liu, K., Peng, B., Yu, Z. and Xu, X., 2017. Fluid-rock interactions during continuous diagenesis of sandstone reservoirs and their effects on reservoir porosity. Sedimentology. 64(5), 1303-1321. 